\title{
Accompaniment the Successful Strategies Based on Research of Customer Loyalty
}

\author{
Khairil Anwar $^{1}$, Retno Dewanti ${ }^{2}$, Tjia Fie Chu ${ }^{3}$ \\ 1,2,3 International Marketing, School of Business Management, BINUS University Jl. Kebon \\ Jeruk Raya No. 27 Kebon Jeruk, Jakarta Barat 11530, Indonesia \\ Email: retnodewanti@binus.edu
}

\begin{abstract}
This study aims to find out the effect of brand awareness and customer satisfaction on corporate image and its impact on customer loyalty in laurier products of PT Kao Indonesia. Customer Loyalty is one of the core goals pursued in modern marketing. By loyalty, it is expected that corporates will get long-term profitability. This study uses quantitative approach and involves 52 respondents in kelurahan Cikoko as the samples collected using probability sampling and simple random sampling techniques. Data processing employs SPSS 24 and the results of the study show that brand awareness, customer satisfaction and corporate image has significant influence on customer loyalty; therefore, the proposed program assistance is necessary to be the strategy in determining the success of customer loyalty of laurier product.
\end{abstract}

Keywords: brand awareness, customer satisfaction, corporate image, customer loyalty.

\section{Introduction}

Industrial World is now facing a new era in increasingly fierce global competition, caused by globalization. Globalization is driven by rapid advances in technology, politics, culture, trade liberalization, and other factors. One of the most popular and prominent global companies is PT. Kao Indonesia, which originated from Japan.

Kao Company started as a domestic soap manufacturing company in 1887 by Mr. Tomiro Nagase in Japan. In the beginning, Mr. Tomiro Nagase and his company only sold goods, not produce them. Until in 1890, Mr. Nagase Shoten began trying to produce exclusive Kao Sekken soap which became the first product for Nagase Sekken.

Kao Company began to expand to Europe; Spain and West Germany, and even the United States. The expansion of Kao Company did not stop here and continued to grow from Asia, Europe, America, Africa, and even Australia. Indonesia is also one of the countries that became the targeted expansion of Kao Company. This company is present in Indonesia with the belief that a clean nation is a prosperous nation. Kao Company established a company in Indonesia in 1977 located on Jl. MT. Haryono Kav. 39 - 40 Jakarta 12770 Indonesia.

PT Kao Indonesia continues to work hard to promote its products to create awareness, attract consumers to make purchases, maintain product quality, and provide customer satisfaction to gain loyalty and profitability in the long run. A good marketing strategy will certainly provide positive results for the company. At the top of the marketing strategy, if all of them have been implemented well, what appears then is Customer Loyalty.

Fornell in Deng (2009: 62) states that high customer loyalty is mainly caused by high customer satisfaction. Boulding in Ali Hasan (2011: 5) argues that consumer loyalty is caused by the influence of customer satisfaction and dissatisfaction with the brand that is accumulated continuously - in addition to perceptions about product quality. Besides customer satisfaction that supports the 
achievement of customer loyalty, brand awareness and corporate image also contribute to achieving optimal customer loyalty. In the sense, corporate image is a set of beliefs and feelings about an organization or company (Dowling, 1988. Leaniz, 2016).

The experience of a company that has a good image or reputation will encourage consumers to buy the products offered, enhance competitiveness, encourage employees' spirit at work, and increase customer loyalty.

In recent digital era, greater dynamics are emerging in the context of customer satisfaction. In creating communication with customers, brands must see whether their customers are sensitive to digital or not. In today's digital era, power is in the hands of customers. According to Barnes (2006), the highest goal of marketing is to achieve the highest level of customer satisfaction. In fact, lately a lot of attention has been devoted to "total" satisfaction, which the implication is that achieving partial satisfaction is not enough to make customers loyal and come back.

Customer loyalty is also influenced by consumer awareness of the brand of products sold by the company (brand awareness). According to Surachman (2008), Brand Awareness is the ability of a prospective buyer to recognize or recall that a brand is part of a particular product category.

\section{Research Methods}

The research design used is associative research. Associative research is more about analysis on relationship where independent variables affect dependent variables. The method used in this research is Quantitative, the target unit is consumers who have randomly bought products of PT Kao Indonesia and information is only collected once at a certain time or also called cross-sectional.

Data and information collection needed in research uses a questionnaire. The population in this study is customers of PT Kao Indonesia's laurier products in kelurahan Cikoko, Pancoran, South Jakarta with 63 residents and with the Slovin formula obtained a sample of 52 respondents. The sampling technique used is Krecjie table. The principle of selection in sampling in this design is that every element in the population has the same opportunity to be selected.

\section{Results and Discussion}

Before going further on the correlation analysis between variables $\mathrm{X} 1, \mathrm{X} 2$, and $\mathrm{Y}$, the structure of causal relationship between variables of brand awareness $\left(\mathrm{X}_{1}\right)$, customer satisfaction $\left(\mathrm{X}_{2}\right)$, corporate image (Y), and customer loyalty (Z) will be shown in Figure 1 below.

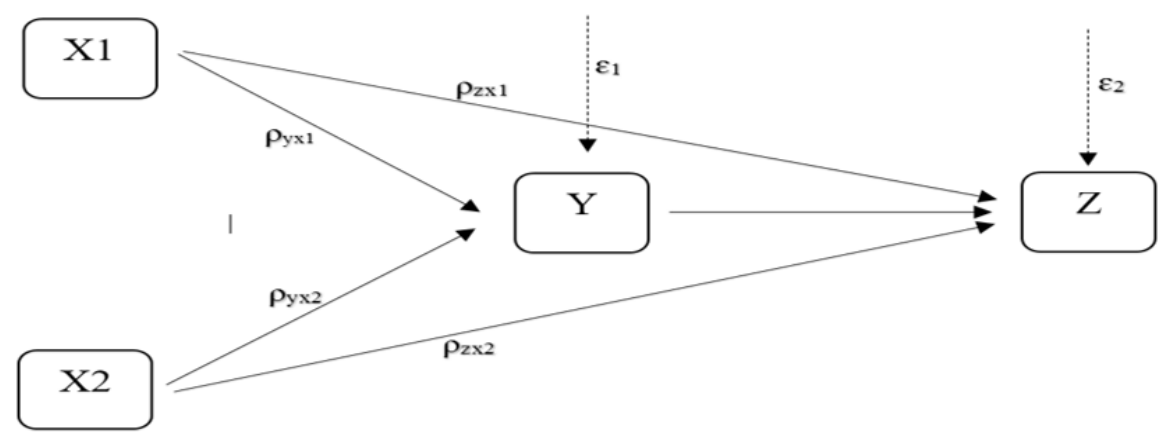

Figure 1 Relationship Structure of X1, X2, Y and Completely Source: Researchers

In the analysis on the influence of brand awareness $\left(\mathrm{X}_{1}\right)$ and customer satisfaction $\left(\mathrm{X}_{2}\right)$ on corporate image (Y) as well as its impact on customer loyalty, further model will be illustrated and referred to as 
correlation. To find out the correlation between variables $\mathrm{X}_{1}, \mathrm{X}_{2}, \mathrm{Y}$ and Z, SPSS 24 program is used with the calculation results summarized in Table 2 as follows.

Table 3 Correlation Results Correlations

\begin{tabular}{|ll|l|l|l|l|}
\hline & & BA (X1) & CS (X2) & CI (Y) & CL (Z) \\
\hline \multirow{3}{*}{ BA (X1) } & Pearson Correlation & 1 & $.473^{*}$ & $.739^{* *}$ & $.665^{*}$ \\
& Sig. (2-tailed) & & .000 & .000 & .000 \\
& N & 100 & 100 & 100 & 100 \\
& Pearson Correlation & $.473^{*}$ & 1 & $.741^{* *}$ & $.836^{* *}$ \\
CS (X2) & Sig. (2-tailed) & .000 & & .000 & .000 \\
& N & 100 & 100 & 100 & 100 \\
& Pearson Correlation & $.739^{* *}$ & $.741^{* *}$ & 1 & $.699^{* *}$ \\
CI (Y) & Sig. (2-tailed) & .000 & .000 & & .000 \\
& N & 100 & 100 & 100 & 100 \\
& Pearson Correlation & $.665^{*}$ & $.836^{* *}$ & $.699^{* *}$ & 1 \\
CL (Z) & Sig. (2-tailed) & .000 & .000 & .000 & \\
& N & 100 & 100 & 100 & 100 \\
\hline
\end{tabular}

*. Correlation is significant at the 0.05 level (2-tailed).

**. Correlation is significant at the 0.01 level (2-tailed).

From the correlation results with data processing using SPSS 24 in Table 3, it can be summarized in Table 4 below;

Table 4 Summary of Correlation Analysis Results

\begin{tabular}{|c|c|c|c|}
\hline No & Inter-variables Relationship & Value & Quality of Relationship \\
\hline 1. & $\begin{array}{l}\text { Brand Awareness }\left(\mathrm{X}_{1}\right) \text { and Corporate } \\
\text { Image }(\mathrm{Y})\end{array}$ & 0.739 & Strong and Unidirectional \\
\hline 2. & $\begin{array}{l}\text { Customer Satisfaction }\left(\mathrm{X}_{2}\right) \text { and Corporate } \\
\text { Image }(\mathrm{Y})\end{array}$ & 0.741 & Strong and Unidirectional \\
\hline 3. & $\begin{array}{l}\text { Brand Awareness }\left(\mathrm{X}_{1}\right) \text { and Customer } \\
\text { Loyalty }(\mathrm{Z})\end{array}$ & 0.665 & Strong and Unidirectional \\
\hline 4. & $\begin{array}{l}\text { Customer Satisfaction }\left(\mathrm{X}_{2}\right) \text { and Customer } \\
\text { Loyalty }(\mathrm{Z})\end{array}$ & 0.836 & Very Strong and Unidirectional \\
\hline 5. & $\begin{array}{l}\text { Corporate Image (Y) and Customer } \\
\text { Loyalty (Z) }\end{array}$ & 0.699 & Strong and Unidirectional \\
\hline
\end{tabular}

Source: SPSS 24 data processing results

Table 5 Model Summary Path Analysis of Sub-structure 1

Source: Data Processing Results of Researchers

Model Summaryb

\begin{tabular}{|c|c|c|c|c|c|c|c|c|c|}
\hline \multirow[t]{2}{*}{ Model } & \multirow[t]{2}{*}{$\mathrm{R}$} & \multirow[t]{2}{*}{ R Square } & \multirow[t]{2}{*}{ Adjusted R Square } & \multirow{2}{*}{$\begin{array}{l}\text { Std. Error of } \\
\text { the Estimate }\end{array}$} & \multicolumn{5}{|c|}{ Change Statistics } \\
\hline & & & & & $\begin{array}{l}\text { R Square } \\
\text { Change }\end{array}$ & $\begin{array}{c}\mathrm{F} \\
\text { Change }\end{array}$ & df1 & $\mathrm{df} 2$ & $\begin{array}{l}\text { Sig. F } \\
\text { Change }\end{array}$ \\
\hline 1 & $.528^{\mathrm{a}}$ & .559 & .514 & .72601 & .559 & 83.075 & 2 & 50 & .000 \\
\hline
\end{tabular}

a. Predictors: (Constant), CS (X2), BA (X1)

b. Dependent Variable: $\mathrm{Cl}(\mathrm{Y})$ 
In Table $5 \mathrm{R}_{\text {square }}=0.559$ is obtained and in Table 6 Anova obtained an $F$ value of 83.075 with a probability value $(\mathrm{sig})=0.000$, as the sig value $<0.05$, the conclusion is $\mathrm{Ho}$ is rejected and $\mathrm{Ha}$ is accepted. Therefore, individual testing can be performed.

Table 6 Anova of Path Analysis of Sub-structure 1 ANOVA ${ }^{a}$

\begin{tabular}{|ll|l|l|l|l|l|}
\hline Model & & Sum of Squares & df & Mean Square & F & Sig. \\
\hline \multirow{4}{*}{1} & Regression & 1250.350 & 2 & 623.675 & 83.075 & $.000^{\mathrm{b}}$ \\
& Residual & 531.127 & 50 & 57.027 & & \\
& Total & 1781.477 & 52 & & & \\
\hline
\end{tabular}

a. Dependent Variable: CI (Y)

b. Predictors: (Constant), CS (X2), BA (X1)

Table 7 Coefficients of Path Analysis of Sub-structure 1 Coefficients $^{\mathrm{a}}$

\begin{tabular}{|ll|l|l|l|l|l|}
\hline \multirow{2}{*}{ Model } & \multicolumn{2}{|l|}{ Unstandardized Coefficients } & $\begin{array}{l}\text { Standardized } \\
\text { Coefficients }\end{array}$ & Sig. \\
\cline { 2 - 5 } & & B & Std. Error & Beta & & \\
\hline \multirow{2}{*}{1} & (Constant) & 29.472 & 9.519 & & 4.763 & .000 \\
& BA (X1) & .338 & .138 & .461 & 2.444 & .000 \\
CS (X2) & .442 & .143 & .515 & 3.292 & .000 \\
\hline
\end{tabular}

a. Dependent Variable: CI (Y)

Source: Data Processing Results of Researchers

Equation of Sub Structure $1 \mathrm{Y}=0.461 \mathrm{x}_{1}+0.515 \mathrm{x}_{2}+0.441 \varepsilon_{1}$

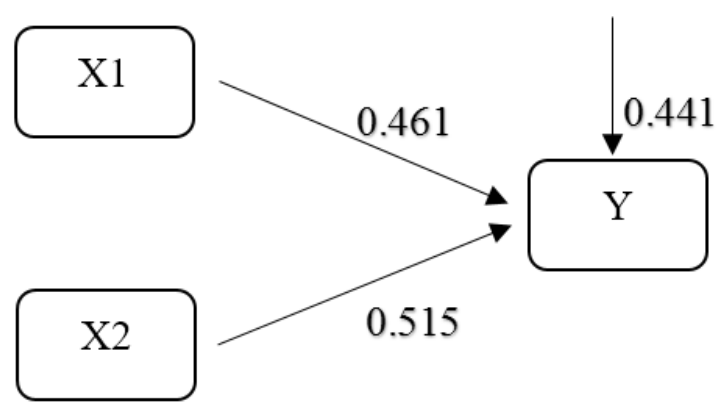

Figure 1 Sub-Structure 1 and Path Coefficient

Source: Data Processing Results of Researchers

The results of Path Analysis on Sub Structure 1 can be explained as follows. The contribution of Brand Awareness $\left(\mathrm{X}_{1}\right)$ that directly influences Corporate Image $(\mathrm{Y})$ is $0.461^{2}=0.212$ or $21.2 \%$. Contribution of Customer Satisfaction $\left(\mathrm{X}_{2}\right)$ that directly influences Corporate Image $(\mathrm{Y})$ is $0.515^{2}=$ 0.265 or $26.5 \%$. Contribution of Brand Awareness $\left(\mathrm{X}_{1}\right)$ and Customer Satisfaction $\left(\mathrm{X}_{2}\right)$ that simultaneously directly influence Corporate Image $(\mathrm{Y})$ is $\mathrm{R}^{2}$ square $=0.559=55.9 \%$. The remaining $0.441=44.1 \%$ is influenced by other factors that cannot be explained in this study. 
Table 8 Model Summary of Path Analysis of Sub-structure 2

Source: SPSS 24 data processing results

Model Summaryb

\begin{tabular}{|c|c|c|c|c|c|c|c|c|c|}
\hline \multirow[t]{2}{*}{ Model } & \multirow[t]{2}{*}{$\mathrm{R}$} & \multirow{2}{*}{$\begin{array}{c}\mathrm{R} \\
\text { Square }\end{array}$} & \multirow{2}{*}{$\begin{array}{l}\text { Adjusted } \\
\text { R Square }\end{array}$} & \multirow{2}{*}{$\begin{array}{l}\text { Std. Error of } \\
\text { the Estimate }\end{array}$} & \multicolumn{5}{|c|}{ Change Statistics } \\
\hline & & & & & $\begin{array}{c}\text { R Square } \\
\text { Change }\end{array}$ & $\begin{array}{c}\mathrm{F} \\
\text { Change }\end{array}$ & df1 & $\mathrm{df} 2$ & $\begin{array}{l}\text { Sig. F } \\
\text { Change }\end{array}$ \\
\hline 1 & $.874^{a}$ & .851 & .839 & .47258 & .851 & 102.575 & 3 & 49 & .000 \\
\hline
\end{tabular}

a. Predictors: (Constant), Cl (Y), CS (X2), BA (X1)

b. Dependent Variable: CL (Z)

In Table $8 \mathrm{R}_{\text {square }}=0.851$ is obtained and in Table 4.19 Anova obtained an F value of 102.575 with a probability value $(\mathrm{sig})=0.000$, as the sig value $<0.05$, the conclusion is Ho is rejected and Ha is accepted. Therefore, individual testing can be performed.

Table 9 Anova of Path Analysis of Sub-structure 2 ANOVAa

\begin{tabular}{|ll|l|l|l|l|l|}
\hline Model & & Sum of Squares & df & Mean Square & F & Sig. \\
\hline \multirow{2}{*}{1} & Regression & 1826.515 & 3 & 578.838 & 102.575 & $.000^{\mathrm{b}}$ \\
& Residual & 91.440 & 49 & 11.023 & & \\
& Total & 1917.955 & 52 & & & \\
\hline
\end{tabular}

a. Dependent Variable: CL (Z)

b. Predictors: (Constant), CI (Y), CS (X2), BA (X1)

Source: SPSS 24 data processing results

Table 10 Coefficients of Path Analysis of Sub-structure 2 Coefficients ${ }^{\mathrm{a}}$

\begin{tabular}{|c|c|c|c|c|c|c|}
\hline \multirow[t]{2}{*}{ Mod } & & \multicolumn{2}{|c|}{ Unstandardized Coefficients } & \multirow{2}{*}{$\begin{array}{l}\text { Standardized } \\
\text { Coefficients } \\
\text { Beta } \\
\end{array}$} & \multirow[t]{2}{*}{$\mathrm{t}$} & \multirow[t]{2}{*}{ Sig. } \\
\hline & & B & Std. Error & & & \\
\hline \multirow{4}{*}{1} & (Constant) & 6.472 & 9.375 & & .726 & .000 \\
\hline & BA (X1) & .410 & .193 & .476 & .263 & .000 \\
\hline & CS (X2) & .795 & .136 & .819 & .246 & .000 \\
\hline & CI (Y) & .649 & .186 & .633 & 6.735 & .000 \\
\hline
\end{tabular}

a. Dependent Variable: CL (Z)

Source: Data Processing Results of Researchers

Equation of Sub Structure $2 \mathrm{Z}=0.467 \mathrm{x}_{1}+0.819 \mathrm{x}_{2}+0.633 \mathrm{y}+0.149 \varepsilon_{2}$

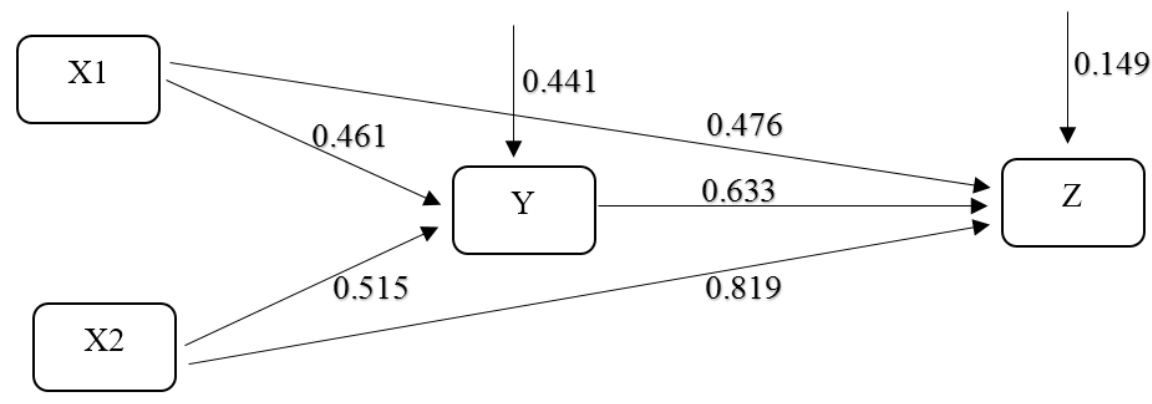


Figure 2 Sub-Structure 2 and Path Coefficient Source: Statistical Output by Researchers

The results of Path Analysis on Sub Structure 2 can be explained as follows. The contribution of Brand Awareness $\left(\mathrm{X}_{1}\right)$ that directly influences Customer Loyalty $(\mathrm{Z})$ is $0.476^{2}=0.226$ or $22.6 \%$. Contribution of Brand Awareness $\left(\mathrm{X}_{1}\right)$ that indirectly influences Customer Loyalty $(\mathrm{Z})$ through Corporate Image $(\mathrm{Y})$ is $0.924^{2}=0.853$ or $85.3 \%$. Contribution of Customer Satisfaction $\left(\mathrm{X}_{2}\right)$ that directly influences Customer Loyalty $(\mathrm{Z})$ is $0.819^{2}=0.670$ or $67 \%$. Contribution of Customer Satisfaction $\left(\mathrm{X}_{2}\right)$ that indirectly influences Customer Loyalty $(\mathrm{Z})$ through Corporate Image $(\mathrm{Y})$ is $1.144^{2}=1.307$ or $130.8 \%$. Contribution of Corporate Image (Y) that directly influences Customer Loyalty $(\mathrm{Z})$ is $0.633^{2}=0.400$ or $40 \%$. Contribution of Brand Awareness $\left(\mathrm{X}_{1}\right)$, Customer Satisfaction $\left(\mathrm{X}_{2}\right)$ and Corporate Image $(\mathrm{Y})$ that simultaneously directly influence Customer Loyalty $(\mathrm{Z})$ is $\mathrm{R}_{\text {square }}^{2}$ $0.851=85.1 \%$. The remaining $0.149=14.9 \%$ is influenced by other factors that cannot be explained in this study.

Table 10 Summary of Path Analysis

\begin{tabular}{|c|c|c|c|c|}
\hline \multirow{3}{*}{ Influence of Variables } & \multicolumn{2}{|c|}{ Causal influence } & \multirow{3}{*}{$\begin{array}{l}\text { Remaining } \\
\mathcal{E}_{1} \& \varepsilon_{2}\end{array}$} & \multirow{3}{*}{ Total } \\
\hline & \multicolumn{2}{|c|}{ Indirect } & & \\
\hline & Direct & Through Y & & \\
\hline $\mathrm{X}_{1}$ on $\mathrm{Y}$ & 0.461 & & & 0.461 \\
\hline $\mathrm{X}_{2}$ on $\mathrm{Y}$ & 0.515 & & & 0.515 \\
\hline $\mathrm{X}_{1}, \mathrm{X}_{2}$ on $\mathrm{Y}$ & 0.559 & & 0.441 & 1 \\
\hline \multirow[t]{2}{*}{$\mathrm{X}_{1}$ on $\mathrm{Z}$} & 0.476 & & & 0.476 \\
\hline & & $0.476+(0.461 \times 0.633)$ & & 0.924 \\
\hline \multirow[t]{2}{*}{$\mathrm{X}_{2}$ on $\mathrm{Z}$} & 0.819 & & & 0.819 \\
\hline & & $0.819+(0.515 \times 0.633)$ & & 1.144 \\
\hline $\mathrm{Y}$ on $\mathrm{Z}$ & 0.633 & & & 0.633 \\
\hline $\mathrm{X}_{1}, \mathrm{X}_{2}, \mathrm{Y}$ on $\mathrm{Z}$ & 0.851 & & 0.149 & 1 \\
\hline$\varepsilon_{1}$ & 0.441 & & & 0.441 \\
\hline$\varepsilon_{2}$ & 0.149 & & & 0.149 \\
\hline
\end{tabular}

\section{Conclusion}

Based on the analysis results of the study that has been conducted on the influence of brand awareness and customer satisfaction on corporate image and its impact on customer loyalty in PT Kao Indonesia, the following conclusions can be drawn. Brand awareness has a strong, unidirectional and significant relationship to corporate image. Directly, brand awareness has a significant influence on corporate image. Customer satisfaction has a strong, unidirectional and significant relationship to corporate image. Directly, customer satisfaction has a significant influence on corporate image. Directly and simultaneously, brand awareness and customer satisfaction have a significant influence on corporate image. Brand awareness has a strong, unidirectional and significant relationship to customer loyalty. Brand awareness directly has a significant influence on customer loyalty. Indirectly, brand awareness has a significant influence on customer loyalty through corporate image. Customer satisfaction has a very strong, unidirectional and significant relationship to customer loyalty. Directly, customer 
satisfaction has a significant influence on customer loyalty. Indirectly, customer satisfaction has a significant influence on customer loyalty through corporate image. Corporate image has a strong, unidirectional and significant relationship to customer loyalty. Directly, corporate image has a significant influence on customer loyalty. Directly and simultaneously, brand awareness, customer satisfaction and corporate image have a simultaneous and significant influence on customer loyalty.

Based on the results of this study, the researchers have several suggestions addressed at two parties, namely for the company (PT Kao Indonesia). PT Kao Indonesia in building or improving its brand awareness must pay attention to the right tools so that it will be effective such as what media are used. At this time, there are a lot of media that can be used both online and offline. However, it seems that online media will be more appropriate to be used at this time such as Youtube, e-articles, e-commerce, online news, social media Instagram, Facebook, Twitter and others. Online media will be even better because we can see consumers who are in line with the segments and targets of PT Kao Indonesia's products and at far cheaper costs. To build brand awareness, PT Kao Indonesia must compile creative and interesting concepts so that the delivery of a brand message to consumers will be easy to remember, the message conveyed must be different from other products, use interesting songs/jingles, use symbols related to the brand, do repetition to improve memory and this becomes very important because usually it is more difficult than making recognition. We can see examples of products that have succeeded in building brand awareness; that is Coca-Cola. The success of Coca-Cola in building brand awareness is inseparable from the marketing team and the cost is certainly huge. Coca-Cola has succeeded in making consumers feel what the message/slogan conveyed, "Happiness".

\section{Bibliography \\ Books}

Aaker, D. A. (2012). Building strong brands. Simon and Schuster.

Cravens, D. W., \& Piercy, N. (2013). Strategic marketing (Vol. 10). New York: McGraw-Hill.

Keller, K. L.(2013). Strategic brand management: Building, measuring, and managing brand equity (4th). Pearson Education Limited. United States.

Schiffman, L., O'Cass, A., Paladino, A., \& Carlson, J. (2013). Consumer behaviour. Pearson Higher Education AU.

Schiffman, L., Wisenblit (2015). Consumer behaviour. England. Pearson Education Limited.

Kotler, P., \& Armstrong, G. (2013). Principles of marketing. Fourteenth Edition. pearson education (South Asia). Singapore

Kotler, P. (2009). Marketing management: A south Asian perspective. Pearson Education India.

Nawangsari, S. Budiman.(2008). Kepuasan Konsumen dan Kesetiaan Terhadap Merek. Jurnal Psikologi, 1(2), 97-103.

Durianto, D. (2008). Brand Equity Ten Strategi Memimpin Pasar. Gramedia Pustaka Utama.

Rochaety, E., Tresnati, R., \& Latief, A. M. (2007). Metodologi penelitian bisnis dengan aplikasi SPSS. Jakarta: MitraWacana Media.

Alma, B. (2013). Manajemen Pemasaran dan Pemasaran Jasa, Edisi Revisi. Bandung. Alfabeta

Van Gelder, S. (2006). Global brand strategy. Journal of Brand Management, 12(1), 39-48. Palgrave Macmillan UK

Kotler, Philip, Kevin Lane Keller, and Taihong Lu. Marketing management in China. Pearson, 2009.

Istijanto, M. M., \& Com, M. (2005). Cara Praktis Mendeteksi Dimensi-Dimensi Kerja

Karyawan. Gramedia Pustaka Utama, Jakarta.

Surachman, S. A. (2008). Dasar-Dasar Manajemen Merek. Malang: Bayu Media Publishing.

Sumarni, M., \& Soeprihanto, J. (2010). pengantar Bisnis. Yogyakarta: Liberty.

Irawan, H. (2008). Indonesia customer satisfaction: membedah strategi kepuasan pelanggan merek pemenang ICSA. Jakarta. PT GramediaPustakaUtama 
Arafat, W. (2008). How to Implement Good Corporate Governance Effectively.Jakarta. Skyrocketing Publisher

Arafat, W. (2008). Good Corporate Governance (GCG): Strategy Execution With Balanced Scorecard Approach.Jakarta. Skyrocketing Publisher

Riduwan \& Kuncoro, E. A. (2014). Cara Menggunakan dan Memakai Analisis Jalur. Edisi Kedua. Bandung: Alfabeta.

Hermawan, Y. P. (2007). Transformasi dalam Studi Hubungan Internasional: Aktor, Isu dan Metodologi. Bandung: Graha Ilmu.

Sitinjak, T., \& Durianto, D. Sugiarto dan Holy Icun Yunarto. 2007. Model Matriks Konsumen: Untuk Menciptakan Superior Customer Value. PT Gramedia Pustaka Utama: Jakarta.

Siregar, S. (2015). Statistika Terapan Untuk Perguruan Tinggi. Jakarta: Prenadamedia Group.

Sarjono, H., \& Julianita, W. (2011). SPSS vs LISREL: sebuah pengantar, aplikasi untuk riset. Jakarta:

Salemba Empat.

Sugiyono, D. Dr (2010). Metode penelitian kuantitatif kualitatif dan R\&D. Penerbit Alfabeta.

Sugiyono, P. Dr. 2012. Metode Penelitian Kuantitatif, Kualitatif dan R\&D. Cetakan Ke-15. Alfabeta:

Bandung.

Blumberg, B. F., Cooper, D. R., \& Schindler, P. S. (2014). Business research methods. McGraw-hill education.

Durianto, D. Sugiarto \& Sitinjak, Toni. (2007). Strategi Menaklukan Pasar Melalui Riset Ekuitas dan Perilaku Merek.

\section{Journals}

Kuo, Y. F., Wu, C. M., \& Deng, W. J. (2009). The relationships among service quality, perceived value, customer satisfaction, and post-purchase intention in mobile value-added services. Computers in human behavior, 25(4), 887-896.

Rego, L. L., Morgan, N. A., \& Fornell, C. (2013). Reexamining the market share-customer satisfaction relationship. Journal of Marketing, 77(5), 1-20.

Abbasi, A. S., Akhter, W., Ali, I., \& Hasan, A. (2011). Factors affecting customer loyalty in Pakistan. African Journal of Business Management, 5(4), 1167-1174.

de Leaniz, P. M. G., \& del Bosque Rodríguez, I. R. (2016). Corporate Image and Reputation as Drivers of Customer Loyalty. Corporate Reputation Review, 19(2), 166-178.

Dowling, G. R. (1988). Measuring corporate images: A review of alternative approaches. Journal of Business Research, 17(1), 27-34.

Douglas, J., Douglas, A., \& Barnes, B. (2006). Measuring student satisfaction at a UK university. Quality assurance in education, 14(3), 251-267. 